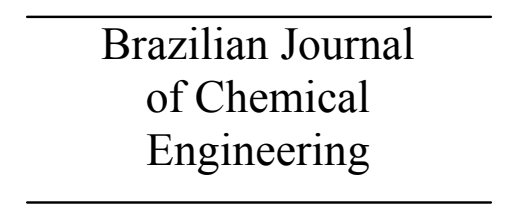

ISSN 0104-6632

Printed in Brazil

www.abeq.org.br/bjche

Vol. 26, No. 04, pp. 669 - 675, October - December, 2009

\title{
SULFIDE TOXICITY KINETICS OF A UASB REACTOR
}

\author{
D. R. Paula Jr. ${ }^{*}$ and E. Foresti ${ }^{2}$ \\ ${ }^{1}$ School of Agriculture Engineering, University of Campinas, UNICAMP, Phone: + (55) (19) 3521-1035, \\ Fax: + (55) (19) 35211010, C. P. 6011, CEP: 13083-970, Campinas - SP, Brasil. \\ E-mail: durval@agr.unicamp.br \\ ${ }^{2}$ São Carlos School of Engineering .University of São Paulo, USP, São Carlos - SP, Brasil.
}

(Submitted: November 17, 2008 ; Revised: June 16, 2009 ; Accepted: July 20, 2009)

\begin{abstract}
The effect of sulfide toxicity on kinetic parameters of anaerobic organic matter removal in a UASB (up-flow anaerobic sludge blanket) reactor is presented. Two lab-scale UASB reactors $(10.5 \mathrm{~L})$ were operated continuously during 12 months. The reactors were fed with synthetic wastes prepared daily using glucose, ammonium acetate, methanol and nutrient solution. One of the reactors also received increasing concentrations of sodium sulfide. For both reactors, the flow rate of $16 \mathrm{~L} \cdot \mathrm{d}^{-1}$ was held constant throughout the experiment, corresponding to a hydraulic retention time of 15.6 hours. The classic model for non-competitive sulfide inhibition was applied to the experimental data for determining the overall kinetic parameter of specific substrate utilization (q) and the sulfide inhibition coefficient $\left(\mathrm{K}_{\mathrm{i}}\right)$. The application of the kinetic parameters determined allows prediction of methanogenesis inhibition and thus the adoption of operating parameters to minimize sulfide toxicity in UASB reactors.

Keywords: UASB reactor; Kinetics, Inhibition coefficient; Sulfide toxicity.
\end{abstract}

\section{INTRODUCTION}

The use of sulfur compounds in industrial processes normally generates sulfate-containing effluents. Pulp and paper, sugar-cane, edible oil, petrochemical, and solvent plants are among those industries producing large amounts of wastewater containing both high sulfate and organic matter concentration. Those industries commonly apply aerobic biological treatments to wastewater in spite of the high operating costs associated with energy consumption. Anaerobic technology for the treatment of high sulfate wastewater faces important restrictions due to several factors, such as competition for the same substrates between sulfate reducing bacteria (SRB) and methanogenic microorganisms (Weijma, 2000; Greben et al., 2000; Visser et al., 1993; Omil et al., 1998; McCartney and Oleszkiewicz, 1993); non-competitive inhibition of methanogenesis caused by SRB-generated sulfide (O'Flaherty et al., 1998; Koster et al., 1986; Hilton and Oleszkiewicz, 1988); and the corrosive and malodorous characteristics of sulfide.

In recent years, some limitations of anaerobic processes applied to sulfate-rich wastewater have been overcome. Among them, competition between acetoclastic methanogenic archaea (AMA) and SRB has been found to be very limited, and dependent on COD (chemical oxygen demand)/sulfate ratio (Isa et al., 1986; Harada et al., 1994; Hulshoff Pol et al., 1998; Cadavid et al, 1999; Damianovic and Foresti, 2007). Although competitive inhibition can be overcome in the anaerobic treatment of sulfate-rich wastewater, non-competitive methanogenesis inhibition due to the sulfide resulting from SRB activity may result in process failure (Speece, 1996, 1993; McCartney and Oleszkiewicz, 1991, 1993; Maillacheruvu et al., 1983; Karhadkar et al., 1987).

Most of the previous studies report on sulfide inhibition associated to the concentration of dissolved sulfide (DS) and hydrogen sulfide $\left(\mathrm{H}_{2} \mathrm{~S}\right)$. As $\mathrm{H}_{2} \mathrm{~S}$ is more toxic to microorganisms than the

*To whom correspondence should be addressed 
dissociated sulfide ions, inhibitory threshold concentrations based on DS are dependent on $\mathrm{pH}$ (Koster et al., 1986). The tolerance of a much higher concentration of sulfide was observed at $\mathrm{pH}$ values in the alkaline range (Oleszkiewicz et al., 1989).

Even so, sulfide may be considered to be an important inhibitory compound due to its toxic effect on the methanogens. According to Speece (1983), sulfide concentrations in the range of 100 to 150 mg. $\mathrm{L}^{-1}$, at a $\mathrm{pH}$ of 6.8 , may lead to severe inhibition of methanogenesis. Koster et al. (1986) found that a free hydrogen sulfide concentration of $250 \mathrm{mg} . \mathrm{L}^{-1}$ led to $50 \%$ inhibition in the $\mathrm{pH}$ range 6.4 to 7.2 .

Most of the inhibition data reported in the literature (Isa et al., 1986; Karhadcar et al., 1987; Hilton and Oleszkiewicz, 1988; McCartney and Oleszkiewicz, 1993) refers to inhibitory sulfide concentrations in different reactors and different wastewater compositions. Information on the effect of sulfide on the overall kinetic parameters is very limited, although important reviews refer to the narrow range separating stimulative from inhibitory sulfide concentrations (Speece, 1983).

The overall kinetic parameters of biological wastewater treatment can be determined assuming the hypothesis of rate-limiting step, using the basic equations which relate microbial growth and substrate utilization. Acting mainly on the methanogenic archae, sulfide is supposed to provoke non-competitive inhibition. Therefore, inhibition should increase progressively with sulfide concentration, causing a gradual decrease of the specific substrate utilization rate (q).

According to Parkin and Speece (1982), noncompetitive inhibition can be described as follows:

$\mathrm{q}_{\mathrm{i}}=\mathrm{q}_{\max } \frac{\mathrm{S}}{\left(\mathrm{K}_{\mathrm{s}}+\mathrm{S}\right)\left(1+\mathrm{i} / \mathrm{K}_{\mathrm{i}}\right)}$

where

$\mathrm{q}_{\mathrm{i}}=$ specific substrate utilization rate in the presence of toxic compounds, time ${ }^{-1}$;

$\mathrm{I}$ = toxicant concentration, mass/volume;

$\mathrm{K}_{\mathrm{i}}=$ inhibition coefficient, mass/volume.

Therefore, for a given value of $\mathrm{q}_{\max }$ and $\mathrm{Ks}$, obtained from a culture in the absence of toxic compounds, it is possible to determine $\mathrm{K}_{\mathrm{i}}$, the inhibition coefficient, from data of $\mathrm{q}_{\mathrm{i}}$, obtained at different toxic concentrations (i).

The main aim of this paper is to report on and discuss data obtained from an anaerobic sludge blanket (UASB) reactor subjected to increasing influent sulfide concentration. The results were used for determining the parameters of equation (1), for evaluating the effect of total sulfide on the process.

\section{MATERIAL AND METHODS}

\section{Experimental Installation Operation and Monitoring}

The experiments were carried out using two identical bench scale apparatuses composed of feed tank, peristaltic pump, 10.5 L UASB reactor and wet gas meter, as schematically shown in Figure 1.

One reactor $\left(R_{1}\right)$ was used for determining the overall kinetic parameters in the absence of sulfide, whereas the other $\left(R_{2}\right)$ was subjected to increasing sulfide concentration for toxicity studies. The experimental apparatus is fully described in Paula Jr. and Foresti (1992).

The synthetic substrate was prepared daily at the required chemical oxygen demand (COD) in $25.5 \mathrm{~L}$ feed tanks and pumped to the reactors. The substrate composition corresponding to a COD of $2 \times 10^{3} \mathrm{mg} . \mathrm{L}^{-1}$ is shown in Table 1. For reactor $\mathrm{R}_{1}$, other values of $\operatorname{COD}\left(4 \times 10^{3}, 6 \times 10^{3}, 8 \times 10^{3}, 10 \times 10^{3}\right.$, and $12 \times 10^{3}$ $\mathrm{mg} . \mathrm{L}^{-1}$ ) were prepared by increasing proportionally all the substrate constituents. The use of the synthetic substrate is justified because adequate operation control is possible and that facilitates a clearer association of cause and effects.

Anaerobic digested sludge from a conventional sewage treatment plant (Vila Leopoldina-SP-Brazil) was used to inoculate the reactor and the start-up period lasted two months.

Both reactors were operated at the substrate COD concentration of $2 \times 10^{3} \mathrm{mg} . \mathrm{L}^{-1}$ and hydraulic retention time $(\theta)$ of 15.6 hours for eight months, including the start-up period of two months, attaining a stable operational condition at $98 \%$ of COD removal efficiency.

Afterwards, the reactors $R_{1}$ and $R_{2}$ were operated for four more months in order to develop the kinetics and toxicity studies. Reactor $\mathrm{R}_{1}$ was subjected to increasing substrate COD concentrations to determine the overall kinetic parameters. Reactor $\mathrm{R}_{2}$ continued to be fed with substrate COD concentration of $2 \times 10^{3}$ mg. $\mathrm{L}^{-1}$, but also received increasing sulfide $\left(\mathrm{Na}_{2} \mathrm{~S}\right)$ concentrations of $10,25,50,100,150,200,300$ and $500 \mathrm{mg} . \mathrm{L}^{-1}$ expressed as total sulfide (TS). The changes in the influent sulfide concentration were only made after verifying that the reactor had adapted to the previous dose applied. That condition was indicated by the similarity of COD values determined for samples taken from the intermediate ports twice a week. 


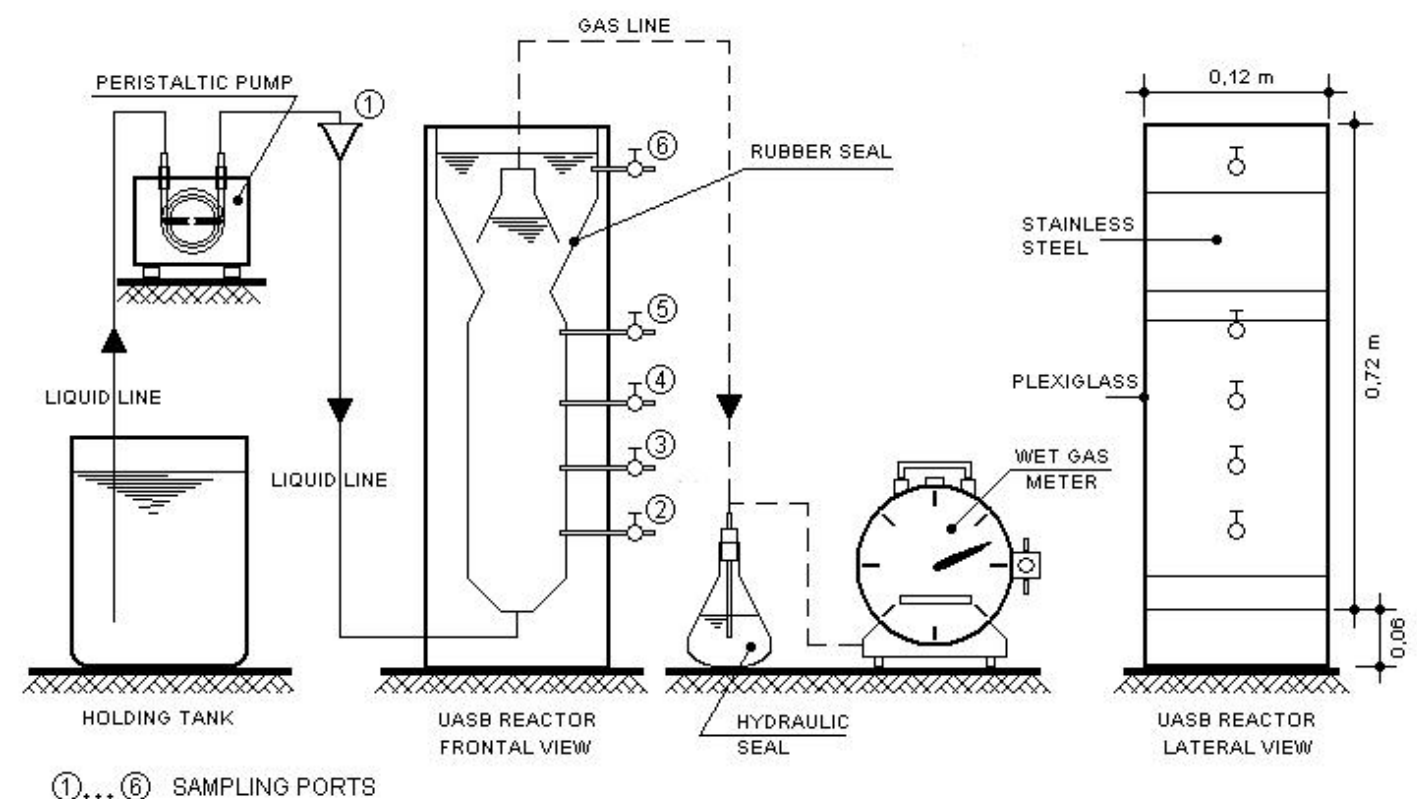

Figure 1: Schematic diagram of the apparatus used during the experiment.

Table 1: Substrate Composition for COD of $2 \times 10^{3} \mathrm{mg} . \mathrm{L}^{-1}$

\begin{tabular}{|l|c|c|r|}
\hline Constituent & $\begin{array}{c}\text { Concentration } \\
\text { (mg. } \mathbf{L}^{-1} \text { ) }\end{array}$ & Constituent & $\begin{array}{c}\text { Concentration } \\
\text { (mg. } \text { - }^{-1} \text { ) }\end{array}$ \\
\hline $\mathrm{C}_{6} \mathrm{H}_{12} \mathrm{O}_{6}$ & 1500.00 & $\mathrm{KH}_{2} \mathrm{PO}_{4}$ & 8.50 \\
$\mathrm{CH}_{3} \mathrm{COONH}_{4}$ & 400.00 & $\mathrm{KH}_{2} \mathrm{PO}_{4}$ & 21.75 \\
$\mathrm{FeSO}_{4} \cdot 7 \mathrm{H}_{2} \mathrm{O}$ & 5.00 & $\mathrm{Na}_{2} \mathrm{HPO}_{4} \cdot 7 \mathrm{H}_{2} \mathrm{O}$ & 33.40 \\
$\mathrm{FeCl}_{3} \cdot 6 \mathrm{H}_{2} \mathrm{O}$ & 0.25 & $\mathrm{NaHCO}_{3}$ & 2000.00 \\
$\mathrm{CaCl}_{2}$ & 44.50 & $\mathrm{NiSO}_{4}$ & 1.00 \\
$\mathrm{CoCl}_{2}$ & 0.08 & $\mathrm{MgSO}_{4} \cdot 7 \mathrm{H}_{2} \mathrm{O}$ & 22.50 \\
$\mathrm{SeO}_{2}$ & 8.50 & $\mathrm{CH}_{3} \mathrm{OH}(99.8 \%)$ & $0.50\left(\mathrm{~mL} . \mathrm{L}^{-1}\right)$ \\
\hline
\end{tabular}

Reactor $\mathrm{R}_{2}$ performance monitoring included COD and VSS determination of samples taken from ports twice a week, total alkalinity (TA) and volatile fatty acids (VFA) of influent and effluent, and gas composition (using gas chromatography equipment CG - 04 model 3537) once a week.

Gas production, influent and effluent $\mathrm{pH}$ and temperature were measured daily. The analyses were carried out according to the Standard Methods for the Examination of Water and Wastewater (APHA, 1998), volatile fatty acids (VFA) as acetic acid according to Dillalo and Albertson (1961) and alkalinity as $\mathrm{CaCO}_{3}$ was according to Ripley et al. (1986).

\section{Determination of Kinetic Parameters}

Different values of $\mathrm{q}$, the overall specific substrate utilization rate $\left(\mathrm{d}^{-1}\right)$, were calculated using equation (2).

$$
\mathrm{q}=\frac{\left(\mathrm{S}_{\mathrm{o}}-\mathrm{S}\right) * \mathrm{Q}}{\mathrm{X} * \mathrm{~V}_{\mathrm{r}}}
$$

where

So $=$ influent COD concentration, $\mathrm{mg} \cdot \mathrm{L}^{-1}$;

$\mathrm{S}=$ effluent $\mathrm{COD}$ concentration, $\mathrm{mg} \cdot \mathrm{L}^{-1}$;

$\mathrm{Q}=$ flow rate, $\mathrm{L} \cdot \mathrm{d}^{-1}$;

$\mathrm{V}_{\mathrm{r}}=$ reactor reaction volume $=5.3 \mathrm{~L}$;

$\mathrm{X}=$ average VSS concentration in the reactor reaction zone, $\mathrm{mg} \cdot \mathrm{L}^{-1}$.

The values of $\theta_{x}$, cellular retention time (d), was estimated from VSS mass balances, according to the equation (3).

$\theta_{\mathrm{x}}=\frac{\mathrm{X}^{*} \mathrm{~V}_{\mathrm{r}}}{\mathrm{M}_{\mathrm{x}}}$

where 
$\theta_{\mathrm{x}}=$ volatile suspended solids (VSS) retention time;

$\mathrm{M}_{\mathrm{x}}=$ mass of VSS lost per day in the reactor in $\mathrm{mg} \cdot \mathrm{d}^{-1}$;

$M_{x}$ values were calculated from the data of effluent VSS concentration, added to a fraction corresponding to losses due to samplings at the intermediate ports, and to excess sludge discharges at port 5. The amounts of VSS due to periodical sampling or eventual sludge discharges were distributed along the respective period of observation and data collection to enable the evaluation of $\theta_{\mathrm{x}}$.

The overall kinetic parameters were estimated from the data obtained from $\mathrm{R}_{1}$, using equations (4) and (5), and considering complete mixing in the reaction zone.

$\mathrm{q}=\mathrm{q}_{\max } * \frac{\mathrm{S}}{\left(\mathrm{K}_{\mathrm{s}}+\mathrm{S}\right)}$

$\frac{1}{\theta_{x}}=y * q-b$

where

$\mathrm{q}=$ specific substrate utilization rate, mass of $\mathrm{COD} /$ mass of VSS per unit of time $(t)$, time $^{-1}$;

$\mathrm{q}_{\max }=$ maximum specific substrate utilization rate, time $^{-1}$;

$\mathrm{S}$ = substrate concentration, mass / volume;

$\mathrm{K}_{\mathrm{s}}=$ Monod half-saturation coefficient, mass / volume;

$\mathrm{y}=$ growth yield coefficient, mass of VSS produced

per mass of substrate consumed;

$\mathrm{b}=$ microbial decay coefficient, time ${ }^{-1}$.

Toxic effects due to sulfide were evaluated by the overall inhibition coefficient $\mathrm{K}_{\mathrm{i}}$, determined from the operational data of the reactor $\mathrm{R}_{2}$, and using a non-competitive inhibition model as follows.

$\mathrm{q}_{\mathrm{i}}=\mathrm{q} * \frac{\mathrm{K}_{\mathrm{i}}}{\mathrm{K}_{\mathrm{i}}+\mathrm{i}}$

where

$\mathrm{q}_{\mathrm{i}}=$ overall specific substrate utilization rate obtained for each concentration of the inhibitor (as mg. $\mathrm{L}^{-1}$ of total sulfide), $\mathrm{d}^{-1}$;

$\mathrm{K}_{\mathrm{i}}=$ global inhibition coefficient for total sulfide, $\mathrm{mg} \cdot \mathrm{L}^{-1}$;

$\mathrm{i}=$ total sulfide concentration, $\mathrm{mg} \cdot \mathrm{L}^{-1}$

Different values of $\mathrm{q}_{\mathrm{i}}$ were determined using equation (6) and the same procedures used for determining $\mathrm{q}$.

\section{RESULTS AND DISCUSSION}

All the data from the experiments were first presented in previous papers (Paula Jr., 1992; Paula Jr. and Foresti, 1992; Paula Jr. and Foresti, 1993). Therefore, the results and discussion presented herein refer only to the overall kinetic parameters obtained from the application of the analytical methods proposed for their evaluation.

The overall kinetic parameters of the UASB reactor were calculated using data from $R_{1}$ which was subjected to a progressive increase of COD concentration from $1,650 \mathrm{mg} . \mathrm{L}^{-1}$ to $4,200 \mathrm{mg} . \mathrm{L}^{-1}$ (The lower range of influent COD concentrations tested in the kinetic studies). The following parameters were obtained by linear regression: $\mathrm{y}=0.23 ; \mathrm{b}=0.04 \mathrm{~d}^{-1} ; \mathrm{K}_{\mathrm{s}}=36 \mathrm{mg} \cdot \mathrm{L}^{-1} ;$ and $\mathrm{q}_{\max }=0.40 \mathrm{~d}^{-1}$. These values are comparable to those found in the literature for anaerobic mixed cultures, although there are evident limitations in this comparison due to differences in the substrate compositions and the sludge characteristics. Moreover, there are limitations associated with the question of complete mixing in the reaction zone of the UASB.

Nevertheless, the kinetic parameters determined can be quite useful for evaluating non-competitive sulfide inhibition using the same reactor and substrate, and assuming the same hypothesis of complete mixing in the reaction zone.

The data obtained from reactor $R_{2}$ made it possible to calculate different values of $\mathrm{q}_{\mathrm{i}}$ for each concentration of sulfide applied, as shown in Table 2. Figure 2 shows that the specific substrate utilization rate $\left(\mathrm{q}_{\mathrm{i}}\right)$ increased for total sulfide concentrations from 0 to $50 \mathrm{mg} . \mathrm{L}^{-1}$, staying steady up to $100 \mathrm{mg} . \mathrm{L}^{-1}$, and decreased gradually for the higher values of inhibitor concentration. From the average values of $\mathrm{q}_{\mathrm{i}}$ obtained with the doses of 100 , $150,200,300$ and $500 \mathrm{mg} . \mathrm{L}^{-1}$ of influent total sulfide, which effectively provoked inhibition of the biological activity, the $K_{i}$ value of equation (6) was obtained by linear regression as shown in Figure 3.

The value $K_{i}=1,462 \mathrm{mg} . \mathrm{L}^{-1}$ represents the inhibitor concentration which provokes a decrease of $50 \%$ in the value of $\mathrm{q}$, the overall specific substrate utilization rate. As this value is almost three times the maximum concentration applied, it seems convenient to limit its validity to the range of sulfide concentrations tested. In fact, it is possible that there exists a limiting concentration of total sulfide which triggers a sequence of events leading the reactor to collapse. 
Table 2: Values of specific substrate utilization rate $\left(q_{i}\right)$ for each concentration of total sulfide (i) applied.

\begin{tabular}{|c|c|c|c|c|c|}
\hline $\mathbf{i}(\mathbf{m g} / \mathbf{l})$ & $\begin{array}{c}\text { So } \\
(\mathbf{m g} / \mathbf{l})\end{array}$ & $\begin{array}{c}\mathbf{S} \\
(\mathbf{m g} / \mathbf{l})\end{array}$ & $\begin{array}{c}\mathbf{X} \mathbf{x} \mathbf{1 0 0 0} \\
(\mathbf{m g} / \mathbf{l})\end{array}$ & $\mathbf{q}_{\mathbf{i}}(\mathbf{l} / \mathbf{d})$ & $\mathbf{l} / \mathbf{q}_{\mathbf{i}}(\mathbf{d})$ \\
\hline- & 1592 & 42 & 29.10 & 0.1608 & 6.2189 \\
10 & 1750 & 40 & 32.00 & 0.1613 & 6.1988 \\
25 & 1845 & 36 & 32.80 & 0.1665 & 6.0061 \\
50 & 2138 & 59 & 36.10 & 0.1739 & 5.7519 \\
100 & 2085 & 68 & 34.90 & 0.1745 & 5.7316 \\
150 & 2110 & 88 & 37.10 & 0.1645 & 6.0778 \\
200 & 2013 & 111 & 35.40 & 0.1622 & 6.1652 \\
300 & 2185 & 272 & 38.40 & 0.1504 & 6.6492 \\
500 & 2295 & 635 & 36.40 & 0.1377 & 7.2635 \\
\hline
\end{tabular}

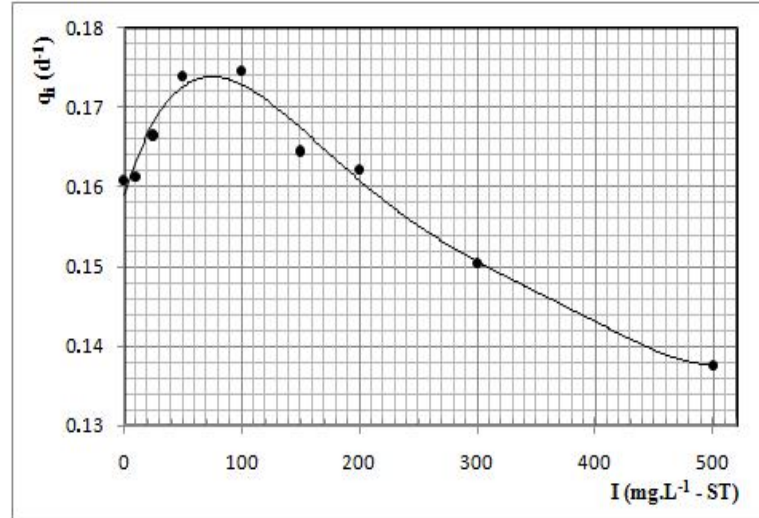

Figure 2: Effects of total sulfide (i) on the specific substrate utilization rate $\left(\mathrm{q}_{\mathrm{i}}\right)$.

However, in the total sulfide concentration range tested, it is possible to express the effect of the continous addition of sulfide on the specific substrate utilization rate given by equation (7) as follows.

$\mathrm{q}_{\mathrm{i}}=\frac{0.4}{36+\mathrm{S}} * \frac{\mathrm{S}}{(1+\mathrm{i} / 1462)}$

There are important considerations to be taken into account regarding the analysis of the experiment and the parameters shown in equation (7). First, it is clear that a complete equation for $\mathrm{q}_{\mathrm{i}}$ should include the stimulatory effects on the reactor operating at total sulfide concentrations below $50 \mathrm{mg} .1^{-1}$. It is well known that there is an inferior limit of free sulfide below which the growth of methanogenic organisms is affected (Speece, 1983). It was experimentally verified that $\mathrm{q}_{\mathrm{i}}$, increased proportionally to the dose of influent total sulfide applied in the range of 0 to $50 \mathrm{mg} \cdot \mathrm{l}^{-1}$. That effect is not expressed in equation (7). Second, as $\mathrm{q}_{\mathrm{i}}$ is a specific rate, sulfide toxicity can be partially prevented by choosing a convenient reactor configuration. In fact, it can be seen from equation (5) that $\mathrm{q}_{\mathrm{i}}$, can be very low if the reactor is

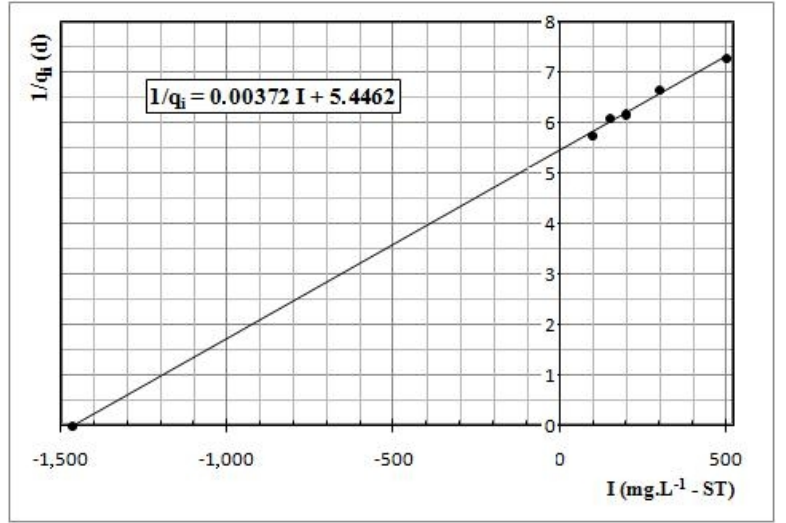

Figure 3: Determination of global inhibition coefficient for total sulfide $\left(\mathrm{K}_{\mathrm{i}}=1462 \mathrm{mg} \cdot \mathrm{L}^{-1}-\mathrm{TS}\right)$

designed to operate at very high values of $\theta_{\mathrm{x}}$, Consequently, the toxic effects would probably be minimized by the presence of a reserve of biomass. Finally, $\mathrm{R}_{2}$ was operated at $\mathrm{pH}$ values ranging from 7.3 (for $100 \mathrm{mg} . \mathrm{L}^{-1}$ of TS) to 7.9 (for $500 \mathrm{mg} . \mathrm{L}^{-1}$ of TS). At these values of $\mathrm{pH}$, the concentration of $\mathrm{H}_{2} \mathrm{~S}$ is very low, and the toxicity effects observed can be clearly related to the dissociated sulfide fraction.

\section{CONCLUSIONS}

From the values of the overall kinetic parameters obtained with the bench-scale UASB reactor operated under a progressive increase of total sulfide concentration at $\mathrm{pH}$ values in the alkaline range, sulfide toxicity could be expressed by the equation:

$\mathrm{q}_{\mathrm{i}}=\frac{0.4}{36+\mathrm{S}} * \frac{\mathrm{S}}{1+\mathrm{i} / 1462}$

where $\mathrm{q}_{i}$ is the specific substrate utilization rate $\left(\mathrm{d}^{-1}\right), \mathrm{S}$ is the substrate concentration $\left(\mathrm{mg} \cdot \mathrm{L}^{-1}\right)$ and $\mathrm{i}$ is the concentration of total sulfide $\left(\mathrm{mg} \cdot \mathrm{L}^{-1}\right)$. 
This equation does not describe the stimulatory effects observed for total sulfide concentrations ranging from 0 to $50 \mathrm{mg} . \mathrm{L}^{-1}$. Therefore, the kinetic parameters $\mathrm{q}=0.40 \mathrm{~d}^{-1}$ and $\mathrm{Ks}=36 \mathrm{mg} \cdot \mathrm{L}^{-1}$ were probably obtained in unfavourable nutritional conditions as regards sulfide requirements.

The model describing the effect of total sulfide on the UASB reactor performance as non-competitive inhibition fitted the experimental data well. Because the value obtained for the overall inhibition coefficient $\mathrm{K}_{\mathrm{i}}$ was slightly lower than three times the maximum inhibitor concentration tested, it is convenient to limit its applicability to the range of 100 to $500 \mathrm{mg} . \mathrm{L}^{-1}$ of total sulfide.

\section{ACKNOWLEDGEMENT}

The authors are grateful to FAPESP - Fundação de Amparo à Pesquisa de Estado de São Paulo for the financial support given to the research.

\section{NOMENCLATURE}

\begin{tabular}{|c|c|}
\hline AMA & $\begin{array}{l}\text { acetoclastic methanogenic } \\
\text { archae }\end{array}$ \\
\hline $\mathrm{b}$ & microbial decay coefficient \\
\hline COD & chemical oxygen demand \\
\hline DS & dissolved sulfide \\
\hline $\mathrm{H}_{2} \mathrm{~S}$ & hydrogen sulfide \\
\hline i & toxicant concentration \\
\hline $\mathrm{K}_{\mathrm{i}}$ & inhibition coefficient \\
\hline $\mathrm{K}_{\mathrm{s}}$ & $\begin{array}{l}\text { Monod half-saturation } \\
\text { coefficient }\end{array}$ \\
\hline M & $\begin{array}{l}\text { mass of volatile suspended } \\
\text { solids within the reactor }\end{array}$ \\
\hline$M_{x}$ & $\begin{array}{l}\text { mass of volatile suspended } \\
\text { solids lost per day in the } \\
\text { reactor }\end{array}$ \\
\hline $\mathrm{Na}_{2} \mathrm{~S}$ & sodium sulfide \\
\hline Q & flow rate \\
\hline $\mathrm{q}$ & $\begin{array}{l}\text { specific substrate utilization } \\
\text { rate }\end{array}$ \\
\hline $\mathrm{q}_{\mathrm{i}}$ & $\begin{array}{l}\text { specific substrate utilization } \\
\text { rate in the presence of toxic } \\
\text { compound }\end{array}$ \\
\hline $\mathrm{q}_{\max }$ & $\begin{array}{l}\text { maximum specific substrate } \\
\text { utilization rate }\end{array}$ \\
\hline $\mathrm{R}_{1}$ & $\begin{array}{l}\text { reactor operated without } \\
\text { sulfide }\end{array}$ \\
\hline$R_{2}$ & reactor operated with sulfide \\
\hline
\end{tabular}

\begin{tabular}{|c|c|}
\hline S & $\begin{array}{l}\text { substrate concentration (as } \\
\text { COD) }\end{array}$ \\
\hline $\mathrm{S}_{0}$ & influent COD concentration \\
\hline SRB & sulfate reducing bacteria \\
\hline & time \\
\hline TA & total alkalinity \\
\hline TS & total sulfide \\
\hline UASB & $\begin{array}{l}\text { upflow anaerobic sludge } \\
\text { blanket }\end{array}$ \\
\hline VFA & volatile fatty acids \\
\hline $\mathrm{V}_{\mathrm{r}}$ & reactor reaction volume \\
\hline VSS & volatile suspended solids \\
\hline $\mathrm{X}$ & $\begin{array}{l}\text { average VSS concentration } \\
\text { in the reaction zone }\end{array}$ \\
\hline$y$ & growth yield coefficient \\
\hline$\theta$ & hydraulic retention time \\
\hline$\theta_{\mathrm{x}}$ & $\begin{array}{l}\text { volatile suspended solids } \\
\text { (VSS) retention time }\end{array}$ \\
\hline
\end{tabular}

\section{REFERENCES}

APHA, Standard methods for the examination of water and wastewater, American Public Health Association, Washington (1998).

Cadavid, D. L., Zayat, M., Foresti, E., Performance of horizontal-flow anaerobic immobilized sludge (HAIS) reactor treating synthetic substrate subjected to decreasing COD to sulphate ratios, Water Science and Technology, Vol. 39, No. 10-11, pp. 99-106, Great Britain (1999).

Damianovic, M. H. R. Z., Foresti, E., Anaerobic degradation of synthetic wastewaters at different levels of sulfate and $\mathrm{COD} /$ sulfate ratios in horizontal-flow anaerobic reactors (HAIB), Environmental Engineering Science, Vol. 24 (3) pp. 383-393 (2007).

Dilallo, R., Albertson, O. E., Volatile acids by direct titration, Journal WPCF, pp. 33, 356-365 (1961).

Greben, H. A., Maree, Aree, J. P., Mnqanqeni, S., Comparison between sucrose, ethanol, and methanol as carbon and energy sources for biological sulphate reduction, Water Science and Technology, 41 (12), pp. 247-253 (2000).

Harada, H., Uemura, S., Momonoi, K., Interaction between sulfate-reducing bacteria and methaneproducing bacteria in UASB reactors fed with low strength wastes containing different levels of sulfate, Water Research, Vol. 28 (2), pp. 355-367 (1994).

Hilton, B. L., Oleszkiewiecz, J. A., Sulphide-induced inhibition of anaerobic digestion, Journal of Environmental Engineering, 114, pp. 1377-1391 (1988). 
Hulshoff Pol, L. W., Lens, P. N. L., Stams, A. J. M., Letinga, G., Anaerobic degradation of sulfate-rich wastewater, Biodegradation.,Vol. 9 (3-4), pp. 213224 (1998).

Isa, Z., Grusenmeyer, S., Verstraete, W., Sulfate reduction relative to methane production in highrate anaerobic digestion: microbiological aspects, Applied and Environmental Biotechnology, 51 (3), pp. 580-587 (1986).

Karhadcar, P. P., Qudic, J., Faup, G. M., Khanna, P., Sulphide and sulphate inhibition of the methanogenesis, Water Research, Vol. 21, pp. 1061-1066 (1987).

Koster, I. W., Rinzema, A., De Vegt, A. L., Letinga, G., Sulfite inhibition of the methanogenic activity of granular sludge at various $\mathrm{pH}$ - levels, Water Research, Vol. 20 (12), pp. 1561-1567, Great Britain (1986).

Maillacheruvu, K. Y., Parkin, G. F., Peng, C. Y., Kuo, W. C., Oonge, Z. I., Lebduschka, V., Sulfide toxicity in anaerobic systems fed sulfate and various organics, Water Environment Federation, Vol. 65 (2), pp. 100-109 (1993).

McCartney, D. M., Oleszkiewicz, J. A., Sulfide inhibition of anaerobic degradation of lactate and acetate, Water Research.,Vol. 25 (2), pp. 203-209 (1991).

McCartney, D. M., Oleszkiewiewcz, J. A., Competition between methanogens and sulphate reducers: effect of $\mathrm{COD} /$ sulphate ratio and acclimatation, Water Environmental Research, Vol. 65, pp. 655664 (1993).

O'Flaherty, V., Mahony, T., O'Kennedy, R., Colleran, E., Effect of $\mathrm{pH}$ on growth kinetics and sulphide toxicity thresholds of a range of methanogenic, syntrophic and sulphate-reducing bacteria, Process Biochemistry, Vol. 33 (5), pp. 555-569 (1998).

Oleszkiewicz, J. A., Marstaller, T., McCartney, D. M., Effect of $\mathrm{pH}$ on sulfide toxicity to anaerobic processes, Environmental Technology Letters, Vol. 10 (9), pp. 815-822 (1989).

Omil, F., Lens, P. N. L.,Visser, A., Hulshoff Pol, L.
W., Lettinga, G., Long term competition between sulphate reducing and methanogenic bacteria in UASB reactor treating volatile fatty acids. Biotechnology and Bioengineering, 57, pp. 676685 (1998).

Parkin, G. F., Speece, R. E., Modeling toxicity in methane fermentation system, Journal of Environmental Engineering, Vol. 108, n ${ }^{\circ} \mathrm{EE} 3$, pp. 515-531 (1982).

Paula Jr., D. R., Toxicity on UASB reactor: Effects of progressive increasing concentrations of sulfide, Ph.D. Thesis, São Carlos School of Engineering (EESC), University of São Paulo (USP), p. 154 (1992).

Paula Jr., D. R., Foresti, E., Kinetic studies on a UASB reactor subjected to increasing COD concentration, Water Science and Technology, Vol. 25 (7), pp. 103-111, Great Britain (1992).

Paula Jr., D. R., Foresti, E., Sulfide toxicity on a UASB reactor, In: ASAE International Winter Meeting, The Society for Engineering in Agricultural, Food, and Biological Systems, ASAE INDEX $\mathrm{N}^{0}$ 93-6522, Chicago, USA (1993).

Ripley, L. E., Boyle, W. C., Converse, J. C., Improved alkalimetric monitoring for anaerobic digestion of high-strength wastes, Journal WPCF, 58, pp. 406-411 (1986).

Speece, R. E., Anaerobic biotechnology for industrial wastewater, Environmental Science and Technology, Vol. 17, No 9, pp. 416-427 (1983).

Speece, R. E., Anaerobic Biotechnology for Industrial Wastewaters, Archae Press, Nashville, Tenessee, USA (1996).

Visser, A., Beekasma, I., Van Der Zee, F., Stams, A. J. M., Lettinga, G., Anaerobic degradation of volatile fatty acids at different sulfate concentrations, Applied Microbiological and Biotechnology, Vol. 40, pp. 549-556 (1993).

Weijma, L., Methanol as electron donor for thermophilic biological sulfate and sulfite reduction, Ph.D. thesis, Wageningen Agricultural University, Wageningen, The Netherlands (2000). 